
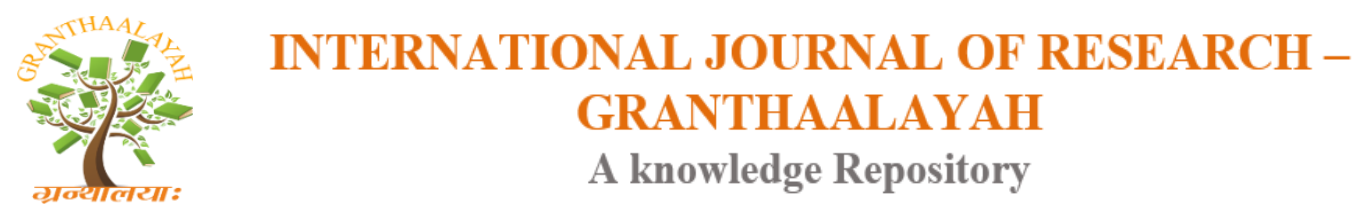

Science

\title{
CHARACTERIZATION AND EVALUATION OF APPEARANCE RICE (Oryza sativa L.) LOCAL EAST TIMOR AND RICE INDONESIA
}

\author{
Abilio Tilman Baptista ${ }^{* 1}$, Damanhuri ${ }^{2}$, Nunun Barunawati ${ }^{2}$ \\ ${ }^{1}$ DepEd Gapan City \\ ${ }^{* 1}$ Graduate School, Faculty of Agricultural, University of Brawijaya, Malang, Indonesia / \\ Betanu Institute Technology of East Timor. \\ ${ }^{2}$ Lecturer, Agricultural, University of Brawijaya, Malang, Indonesia
}

\begin{abstract}
Rice is an important commodity for the majority of the population, especially in the continent of Asia use rice as a staple food. The state of Indonesia and East Timor, rice as the main food source that needs continue to increase because in addition to the population continues to grow at a rate of increase of about $2 \%$ per year, as well as the change in consumption pattern of the population of non-rice to the rice. Interest characterization and evaluation of the appearance of rice(Oryza Sativa L.) locally Timor Leste and Indonesian rice are getting Local rice genotypes Timorese suitable for cultivated in paddy fields. This research using a randomized block design (RBD) consisted of 9 treatments and 3 replications. The materials used are high-yielding rice varieties namely IR-3 64, Ciherang, Cimelati and 6 local rice genotypes Timor Leste, namely Hare Foam, Fafulu Hare, Hare Bauk Morin, Mean Hare, Hare and Hare Modok Fulan. Results showed that the highest plant length at the age of 10 MST contained in the local rice Hare Bauk Morin(134.67 cm), Number of tillers(40.30) the number of leaves(4.64).Flowering date and time of harvest shortest genotypes present in Morin namely Hare Bauk flowering date (39 days) and time of harvest (105 days). The highest number of panicles contained in Hare Mean genotype, high-yielding varieties IR64, Ciherang and Cimelati. The length of the longest panicle genotypes present in Foam Hare, Hare Hare Fafulu, and Fulan. The number of filled grains per panicle most contained in superior varieties IR64, Ciherang and Cimelati. The highest weight of 1000 grains contained in Cimelati varieties (vu3) with Hare Bauk Morin, IR64 and Cherang varieties. The highest rice yield for local rice genotypes present in Hare Bauk Morin (G3) of 9.79 ton. $\mathrm{Ha}^{-1}$ while yielding varieties there exist varieties Cherang (vu2) of 9.74 ton. $\mathrm{Ha}^{-1}$.
\end{abstract}

Keywords: Superior Rice; Genotype Local Rice East Timor.

Cite This Article: Abilio Tilman Baptista, Damanhuri, and Nunun Barunawati. (2018). "CHARACTERIZATION AND EVALUATION OF APPEARANCE RICE (Oryza sativa L.) LOCAL EAST TIMOR AND RICE INDONESIA." International Journal of Research Granthaalayah, 6(2), 120-129. https://doi.org/10.5281/zenodo.1186605. 


\section{Introduction}

Rice (Oryza sativa L.) is a staple food as a source of calories consumed by the people of Indonesia (BPS, 2014). Rice is generally consumed by the public as an important food source in Asia, particularly the East Timorese nation. Approximately $90 \%$ of the production and consumption of rice is in Asia. The average annual consumption per person in 2007 from $131 \mathrm{~kg}$ and the content of rice per $100 \mathrm{~kg}$ of material provides $360 \mathrm{kcal}$ of energy, $79.34 \mathrm{~g}$ carbohydrates, $6.6 \mathrm{~g}$ protein and $0.58 \mathrm{~g}$ fat (FAOSTAT 2011). Particularly in Indonesia and East Timor, rice as a main food source that needs continue to increase, because in addition to the population continues to grow at a rate of increase of about $2 \%$ per year, as well as the change in the pattern of consumption of the population of non-rice to the rice and the increasingly limited capacity of rice production paddy varieties developed due to the very limited too (Sadimantara and Muhidin, 2013).

The average rice production in Indonesia in 2015 was 5.3 tonnes/ha, while the average consumption per capita rice Indonesian people per week reached 1,626 kg (CBS, 2015). Indonesian population growth rate from 2010- 2014 to reach $1.4 \%$ per year and projected to the total population of 2015 were approximately 255 million reached 296 million in 2025 (CBS, 2015). Until now rice production in Indonesia is still not comparable with the needs of the community rice prompted the government to always provide an increase rice production in sufficient quantities (Ministry of Agriculture, 2015). Increased rice production needs to be backed rice germplasm collection as its genetic material.

One of the factors that led to reduced production of rice is of the variety or the genetic makeups of the rice plants are not resistant to the environment. Environmental factors that can affect the growth and production of rice can be divided into two groups, namely: factors of the natural environment such as soil, climate and biological as well as factors of production inputs (fertilizers, pesticides, rice varieties excel and others ), given by humans. While genetics can be determined by estimating the heritability value shows how much the tendency of characters genetic diversity of the plants or phenotypes to respond to the environment in which these plants are cultivated (Nugroho et al.,2017).

\section{Materials and Methods}

This study was conducted between July and October 2017, located in the garden village farmers Sumberbendo subdistrict Pare Kediri, East Java, Indonesia. Field trials at an altitude of $125 \mathrm{~m}$ above sea level, soil type Regosol grayed brown, the average maximum temperature of $30.7^{\circ} \mathrm{C}$ during the dry season and an average minimum temperature of $23.8^{\circ} \mathrm{C}$, in the rainy season. The average air humidity of $85.5 \%$ per year, while relative humidity of $74 \%$.

\subsection{Samples}

Materials used include 3-yielding varieties that IR64, Ciherang, Cimelati and 6 local rice genotypes Timor Leste, namely Hare Foam, Fafulu Hare, Hare Bauk Morin, Mean Hare, Hare and Hare Modok Fulan. Fertilizer use Urea, Phosphate, SP 36 and the pesticides used are Alfamex-Bamec-Numectin-Demolish (the active ingredient abamectin) 


\subsection{Research design}

Research using a randomized block design (RBD) consisted of 9 treatments and 3 replications.

\subsection{Statistical analysis}

The data analysis was facilitated by the 2010 version of Microsoft Excel using analysis of variance (F-test with a 5\% standard error) Followed by a least significant difference (LSD) approach.

\section{Results and Discussion}

\subsection{Results}

Based on the analysis of variance showed that the real treatment effect on plant length and the number of leaves at the age of 6 WAP, 8 WAP and 10 WAP (Tables 1 and 2).

Table 1: Average length of rice plants aged 6,8 and 10 weeks after planting the varieties treatment.

\begin{tabular}{|l|l|l|l|}
\hline \multirow{2}{*}{ Treatment } & \multicolumn{3}{|c|}{ Plant Length $\mathbf{( c m )}$} \\
\cline { 2 - 4 } & 6 WAP & 8 WAP & 10 WAP \\
\hline Hare Foam (G1) & $89.50 \mathrm{~b}$ & $116,83 \mathrm{c}$ & $125.90 \mathrm{~cd}$ \\
\hline Hare Fafulu (G2) & $91,63 \mathrm{bc}$ & $117.10 \mathrm{c}$ & $124.80 \mathrm{~cd}$ \\
\hline Hare Bauk Morin (G3) & $122.33 \mathrm{e}$ & $132.90 \mathrm{~d}$ & $134.67 \mathrm{~d}$ \\
\hline Hare Fulan (G4) & $100.00 \mathrm{c}$ & $115.67 \mathrm{c}$ & $123.53 \mathrm{c}$ \\
\hline Hare Modok (G5) & $117,77 \mathrm{de}$ & $124.67 \mathrm{~cd}$ & $129.13 \mathrm{~cd}$ \\
\hline Hare Mean (G6) & $110.93 \mathrm{~d}$ & $124.00 \mathrm{~cd}$ & $126.63 \mathrm{~cd}$ \\
\hline varieties IR64 (VU1) & $61.83 \mathrm{a}$ & $69.83 \mathrm{a}$ & $71.88 \mathrm{a}$ \\
\hline variety Ciherang (vu2) & $70.27 \mathrm{a}$ & $76.00 \mathrm{ab}$ & $76.87 \mathrm{ab}$ \\
\hline varieties Cimelati (vu3) & $69.77 \mathrm{a}$ & $82,77 \mathrm{~b}$ & $83.25 \mathrm{~b}$ \\
\hline LSD 5\% & 10.04 & $9: 14$ & 10.33 \\
\hline
\end{tabular}

Description: Numbers are accompanied by the same letter at the time of observation each showed no significant difference based on LSD 5\%; $\mathrm{cm}=$ centimeter, WAP $=$ weeks after planting.

Table 2: Average number of leaves of rice plants aged 6,8 and 10 weeks after planting the varieties treatment.

\begin{tabular}{|l|l|l|l|}
\hline \multirow{2}{*}{ Treatment } & \multicolumn{3}{|c|}{ Leaf Number } \\
\cline { 2 - 4 } & 6 WAP & 8 WAP & 10 WAP \\
\hline Hare Foam (G1) & $3.26 \mathrm{a}$ & $3.40 \mathrm{a}$ & $3.48 \mathrm{a}$ \\
\hline Hare Fafulu (G2) & $3,38 \mathrm{ab}$ & $3.60 \mathrm{ab}$ & $3.63 \mathrm{ab}$ \\
\hline Hare Bauk Morin (G3) & $\mathrm{d} 4.33$ & $4.62 \mathrm{de}$ & $4.64 \mathrm{~d}$ \\
\hline Hare Fulan (G4) & $3.55 \mathrm{bc}$ & $\mathrm{bc} 3.72$ & $3.70 \mathrm{~b}$ \\
\hline Hare Modok (G5) & $3.77 \mathrm{c}$ & $3.89 \mathrm{c}$ & $3.91 \mathrm{c}$ \\
\hline Hare Mean (G6) & ab 3,48 & $3,75 \mathrm{bc}$ & $3,78 \mathrm{bc}$ \\
\hline
\end{tabular}




\begin{tabular}{|l|l|l|l|}
\hline variety IR64 (VU1) & $4.52 \mathrm{de}$ & $4.57 \mathrm{~d}$ & $4.60 \mathrm{~d}$ \\
\hline Variety Ciherang (vu2 ) & $4.69 \mathrm{e}$ & $4.75 \mathrm{de}$ & $4.79 \mathrm{~d}$ \\
\hline Variety Cimelati (vu3) & $4.73 \mathrm{e}$ & $4.78 \mathrm{e}$ & $4.80 \mathrm{~d}$ \\
\hline BNT 5\% & 0.25 & 0.21 & 0.21 \\
\hline
\end{tabular}

Description: Numbers are accompanied by the same letters at the same time observation showed no significant difference based on LSD 5\%; WAP = weeks after planting.

Table 3: Average number of seedlings of rice plants is 2, 4, 6, 8 and 10 weeks after planting the varieties treatment

\begin{tabular}{|l|l|l|l|l|l|}
\hline \multirow{2}{*}{ Treatment } & \multicolumn{5}{|c|}{ Number of Tillers } \\
\cline { 2 - 6 } & 2 WAP & 4 WAP & 6 WAP & 8 WAP & 10 WAP \\
\hline Hare Foam (G1) & $2.34 \mathrm{a}$ & $14.11 \mathrm{~b}$ & $18.87 \mathrm{ab}$ & $20.23 \mathrm{a}$ & $20.41 \mathrm{a}$ \\
\hline Hare Fafulu (G2) & $2.33 \mathrm{a}$ & $13.16 \mathrm{ab}$ & $21.57 \mathrm{~b}$ & $24.40 \mathrm{ab}$ & $25.07 \mathrm{bc}$ \\
\hline Hare Bauk Morin (G3) & $3.14 \mathrm{~d}$ & $18.33 \mathrm{c}$ & $3114 \mathrm{~d}$ & $39.97 \mathrm{a}$ & $40.30 \mathrm{~d}$ \\
\hline Hare Fulan (G4) & $2.44 \mathrm{a}$ & $11.83 \mathrm{a}$ & $16.27 \mathrm{a}$ & $21.97 \mathrm{~b}$ & $21.97 \mathrm{ab}$ \\
\hline Hare Modok (G5) & $2.60 \mathrm{~b}$ & $14.83 \mathrm{~b}$ & $25,13 \mathrm{c}$ & $26.90 \mathrm{~b}$ & $26.90 \mathrm{c}$ \\
\hline Hare Mean (G6) & $2.66 \mathrm{~b}$ & $14.50 \mathrm{~b}$ & $26.67 \mathrm{c}$ & $28.17 \mathrm{~b}$ & $28.17 \mathrm{c}$ \\
\hline varieties IR64 (VU1) & $3.10 \mathrm{~d}$ & $22.11 \mathrm{~d}$ & $43,00 \mathrm{f}$ & $47.97 \mathrm{~d}$ & $47.97 \mathrm{e}$ \\
\hline varieties Ciherang (vu2) & $2.89 \mathrm{c}$ & $24.38 \mathrm{e}$ & $43.53 \mathrm{f}$ & $47.90 \mathrm{~d}$ & $47.90 \mathrm{e}$ \\
\hline varieties Cimelati(vu3) & $3.39 \mathrm{e}$ & $19.33 \mathrm{c}$ & $35,47 \mathrm{e}$ & $41.03 \mathrm{c}$ & $41.20 \mathrm{~d}$ \\
\hline LSD 5\% & 0.11 & $2: 19$ & 3.27 & 4.37 & 4.09 \\
\hline
\end{tabular}

Description: Numbers are accompanied by the same letter at the same time observation showed no significant difference based on LSD 5\%; WAP = weeks after planting.

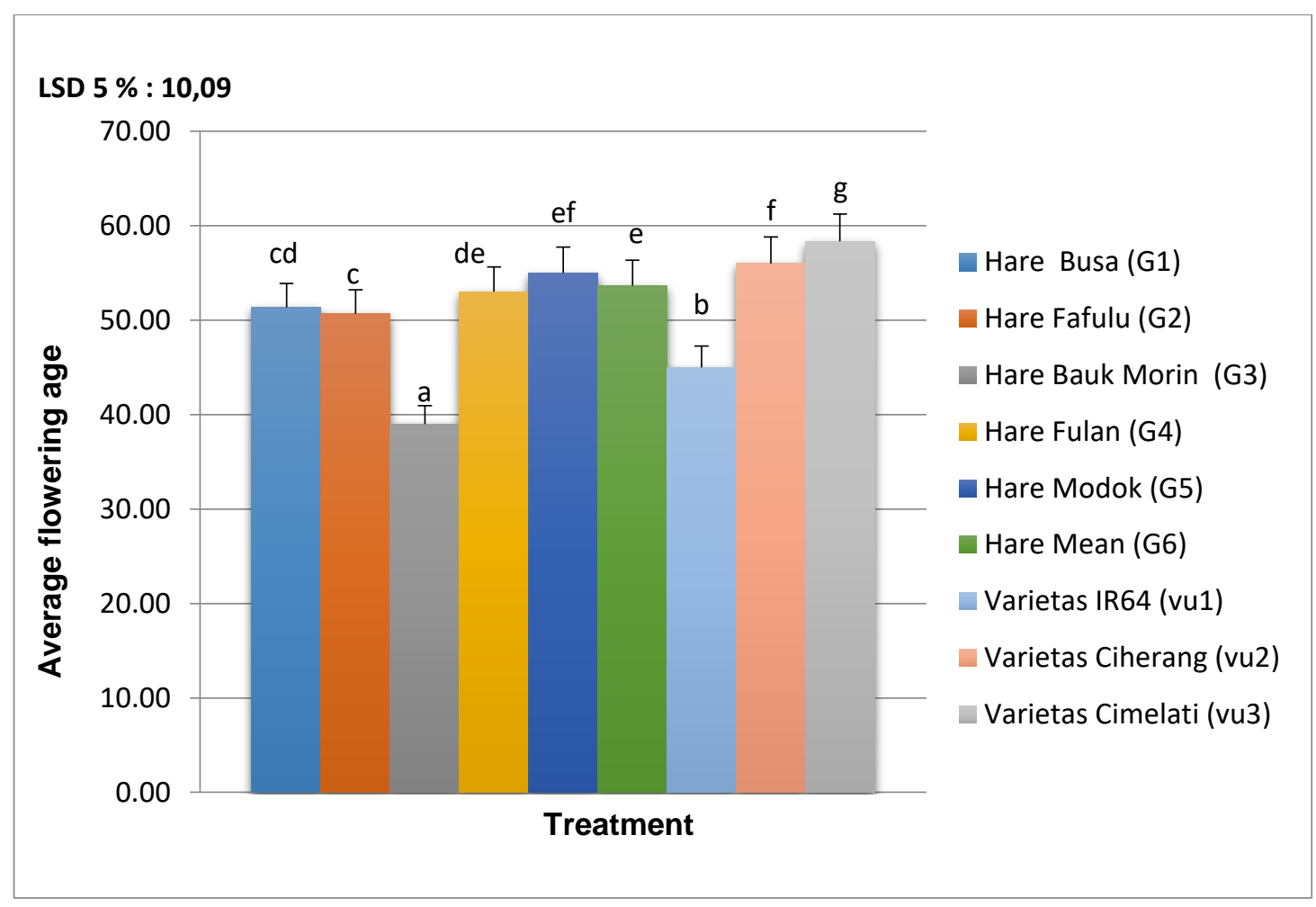

Figure 1: The Flowering Age 


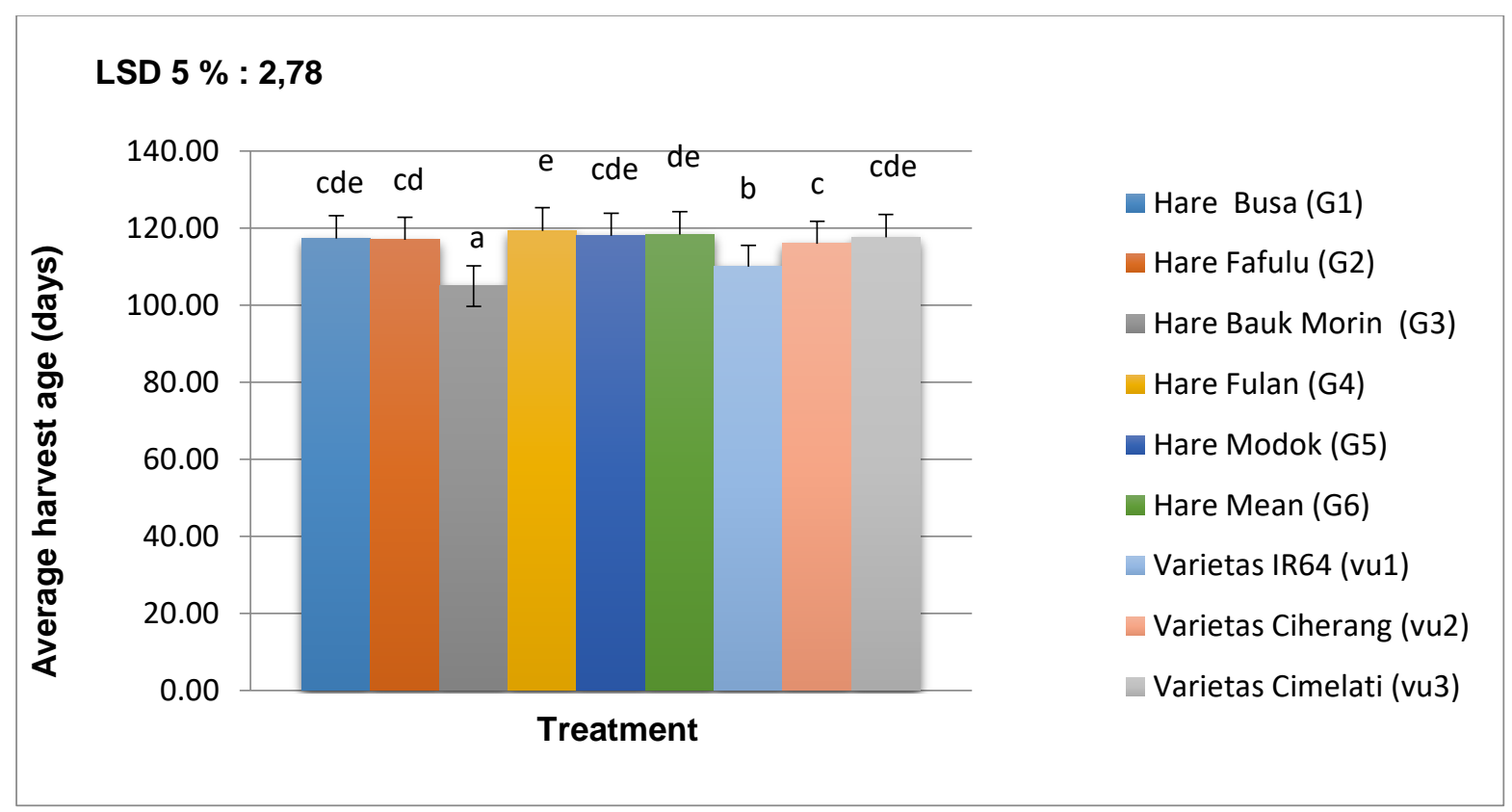

Figure 2: The harvest age

\section{LSD 5\%:0.76}

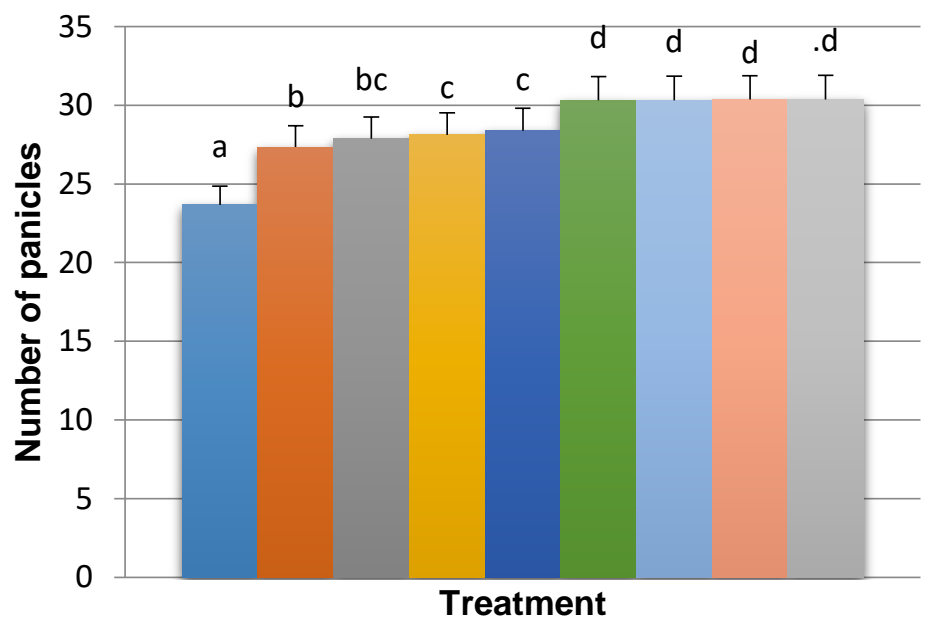

- Hare Busa (G1)

- Hare Fafulu (G2)

- Hare Bauk Morin (G3)

Hare Fulan (G4)

- Hare Modok (G5)

- Hare Mean (G6)

- Varietas IR64 (vu1)

Varietas Ciherang (vu2)

Varietas Cimelati (vu3)

Figure 3: Number of panicles 


\section{LSD $5 \%: 1.04$}

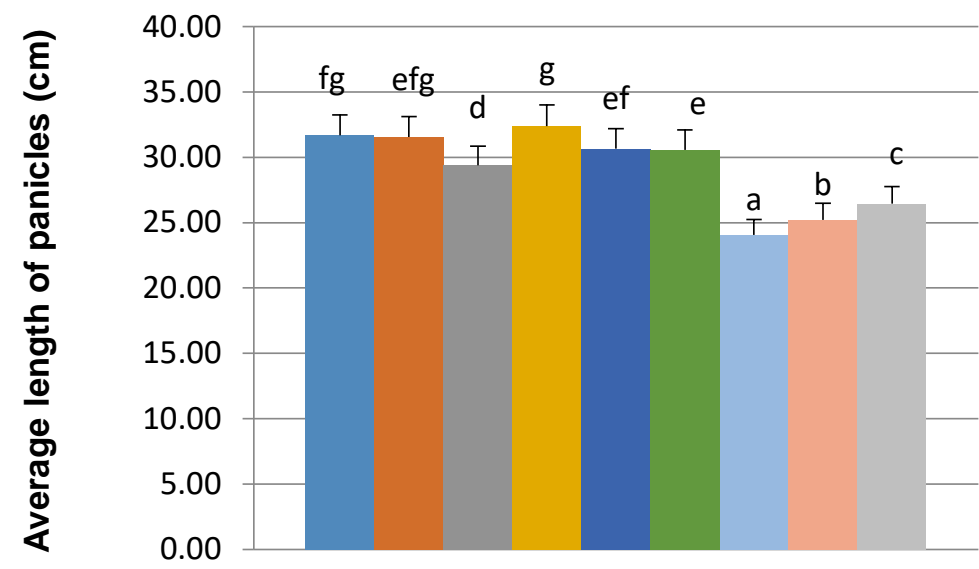

- Hare Busa (G1)

- Hare Fafulu (G2)

- Hare Bauk Morin (G3)

Hare Fulan (G4)

- Hare Modok (G5)

- Hare Mean (G6)

Varietas IR64 (vu1)

Varietas Ciherang (vu2)

- Varietas Cimelati (vu3)

Treatment

Figure 4: The length of the rice panicle

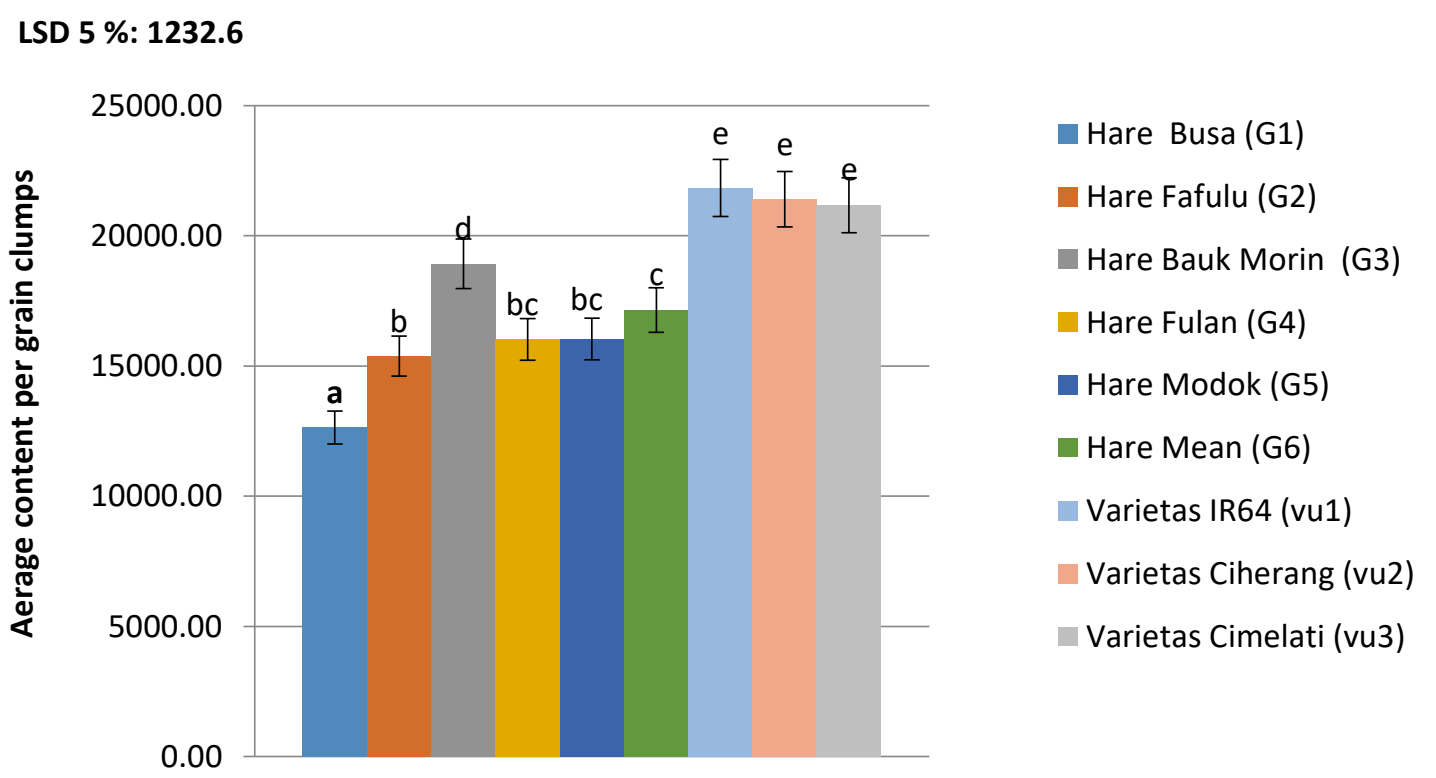

Figure 5: The average content per grain clumps 


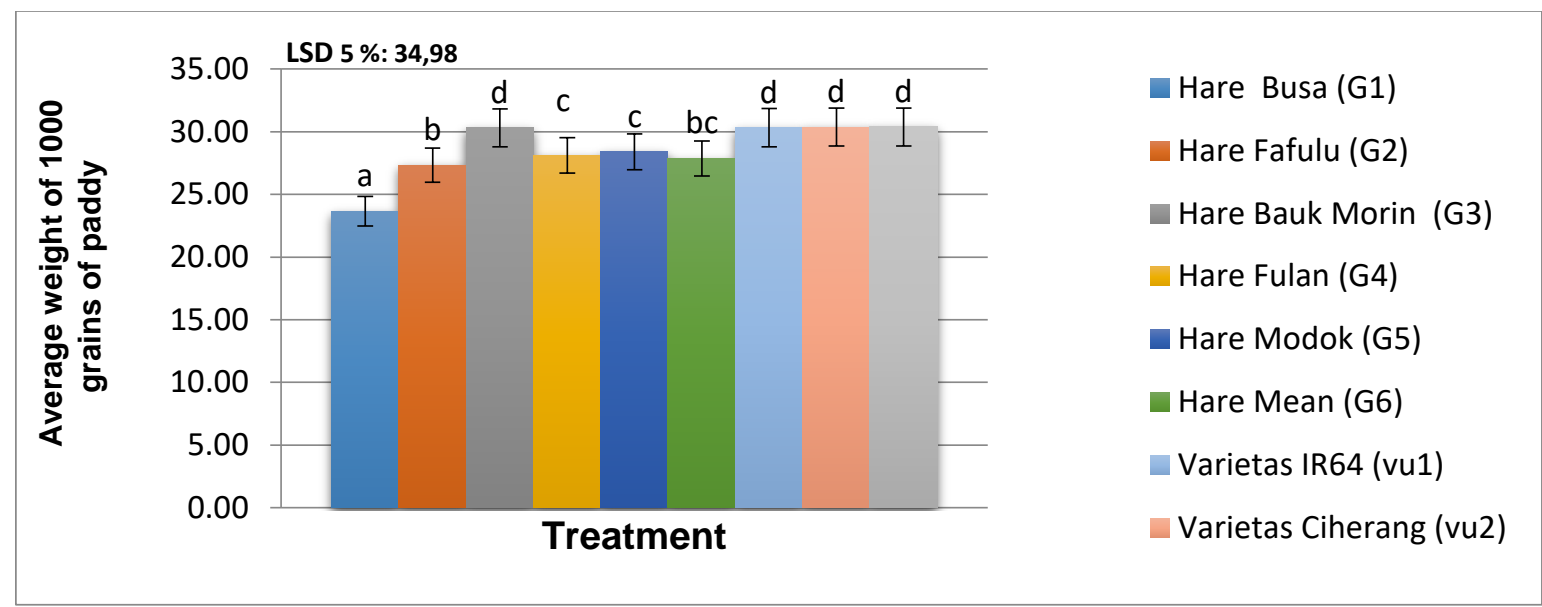

Figure 6: Weight of 1000 grains of grain

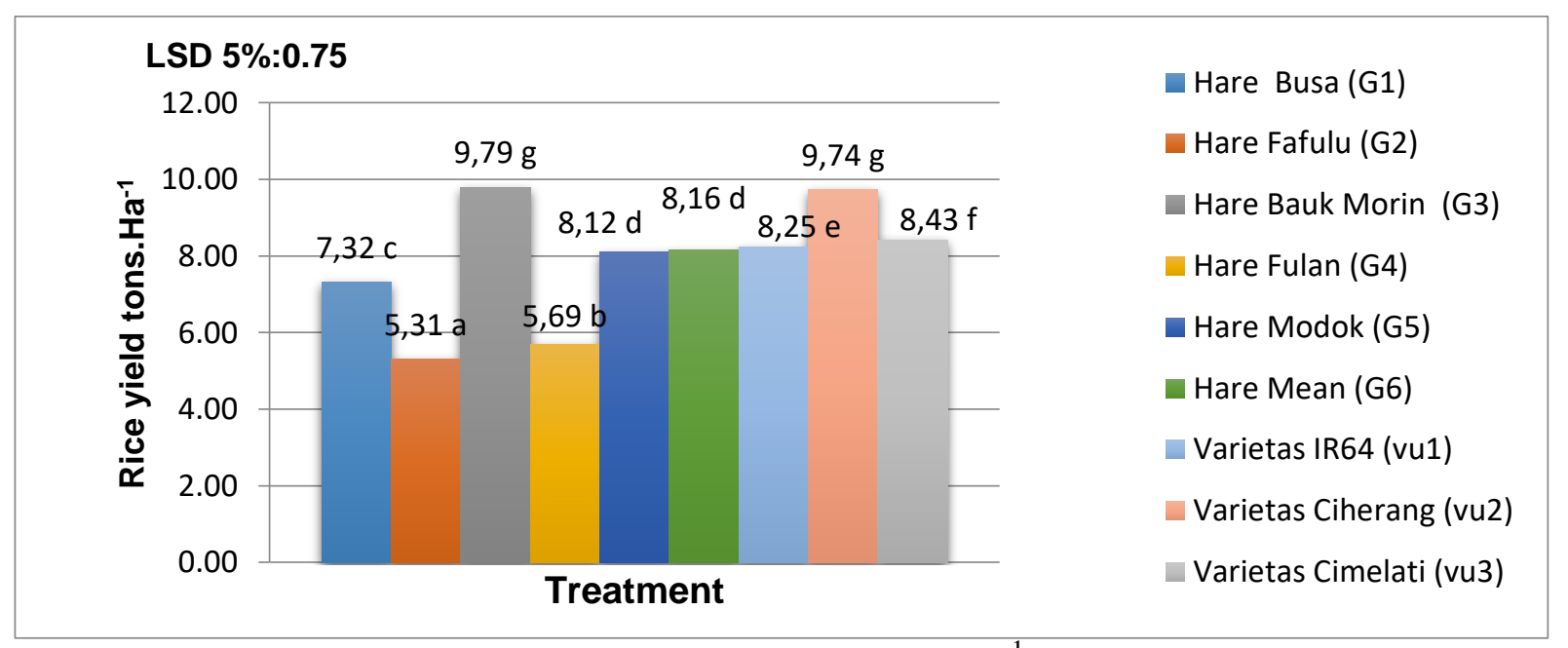

Figure 7: Rice yield tons. $\mathrm{Ha}^{-1}$

\section{Discussion}

Plant growth can be interpreted as a quantitative change in the plant life cycle that cannot be returned (irreversible) or increase the size of the plant will not be back due to the division and cell enlargement. Changes in body size as well as increase overall plant represents a space or volume permanently or increase the volume of which cannot be returned (Irreversible Increase in volume). The growth process is controlled by two factors, namely plant genetic and environmental factors (Sitompul and Guritno, 2012).

The growth of rice plants has different responses to the growing environment. It is suspected that genetic factors and the environment that supports the growth could spur plant growth component that is higher than the growth environment that does not support. Lehar (2012) states that genetic factors are more dominant on the characters displayed plant for genetic factors contribute greater than environmental factors. Plants that have a high genetic diversity will greatly help a population to adapt to the changes occurring in the surrounding environment (Nugroho et al., 2017). In addition to genetic factors, environmental factors around the place of growing plants are also the very important role in the growth and yield of the (Lehar et al., 2017). 
Photosynthesis is affected by two factors: genetic factors and environmental factors. Genetic factors include differences between the species, the influence of leaf age, and influence the rate of translocation fotosintat. Environmental factors include the availability of water, availability of $\mathrm{CO} 2$, the influence of light, as well as the influence of temperature (Lakitan, 2007). Chlorophyll formation is influenced by several factors such as plant genetic factors, an intensity of light, oxygen, carbohydrates, nutrients, water, and temperature (Dwijoseputro, 1992).

Local rice is generally grown in areas of dry land by the public in the State of East Timor and some people cultivate in the rainfed areas. Wetland and dry land are still many obstacles in improving rice growth both in terms of nutrients in the soil and rice varieties are used. One way to improve rice growth by the use of organic fertilizer chicken manure as fertilizer base will support the rice plants growing environment and selects local rice genotypes that can adapt to the wetlands. Alavan et al.,(2015) states that local rice grown in dryland or rainfed areas not everything can be adapted in the wetlands it is due to genetic factors of the plants cannot grow well in wetlands. Selanjuta Alavan et al.,(2015) stated that the rice plants grow well when the environment around where the plants grow to support the growth of these plants.

The rice plant local varieties and improved varieties can grow well if the nutrient and growing environment around the plant is very supportive. Doberman and Fairhust, (2000) suggest growing environment that supports and enough nutrients available will be easily absorbed by the plant so as to accelerate the growth of plants, in this case adds plant height, number of tillers, increase the size of leaves and large grain and improve the quality of crops and seeds, increase the protein content of rice, increase the number of grains and the percentage of filled grain. The wetlands with the state of soil texture and structure strongly support plant growth, in line with the opinions Osman (1996) states that the land with the state of texture and structure greatly to the success of farming soil to the desired crop is the soil structure loose has a pore space is filled with water and air, so that the absorption of nutrients can run optimally (linga 1998). Manure can add nutrients to the soil as a supply of humus that can improve soil structure and encourage the life of soil microorganisms (Lehar, 2012).

Environmental grow a plant needs to be considered in the cultivation of a plant, it is to ensure the growth of the plant. Osman (1996) states that the land with the state of texture and structure greatly to the success of farming soil to the desired crop is the structure of loose soil have pore spaces are filled with water and air so that the absorption of nutrients can run optimally (linga 1998). Manage water which can improve the circulation of air in the soil and manure as basal fertilizer to add nutrients in the soil as a supply of humus to improve soil structure and encourage the life of microorganisms soil to improve plant growth (Kato et al., 2009).

Rice productivity in the local commonly cultivated in dry land and when cultivated in the wetlands, the growth of the plant is not stable so that growth and the results are low, due to the effect of pressure abiotic puddles continuous and nutrients is not enough (Sarangi et al., 2014; Sarangi et al.,2016). Pressure abiotic delaying or reducing the growth of seedlings of rice inhibits root growth and elongation of shoots, produces components uneven growth, and ultimately lead to loss of crops (Sipaseuth et al.,2007; Guan et al.,2009; Ismail et al., 2009), 
One effort that can be done is through the test of the stability of the superior properties possessed by each variety produced in order to obtain improved varieties that are able to adapt and interact in a specific environment (Edi Mukhlis, 2000). It is a condition of the success of the selection of the nature/character of the desired plant (Burmana et al., 2017). Interaction with the environment varieties gets extra attention for plant breeders in an effort to get local varieties for high yield (Guan et al.,2009; Kumar, and Ladha, 2011; Wang et al.,2017). Important properties are targets for improvement of local rice varieties grown in wetlands, among others, high yield, tolerant to diseases, have a good quality of rice (Lopez et al., 2008; You et al., 2006.

\section{Conclusion}

The results of this study concluded that characterization and evaluation of the appearance of rice(Oryzasativa L.) local Timorese and Indonesian rice obtained the highest plant length at the age of 10 MST contained in the local rice Hare Bauk Morin(134.67 cm), number of tillers(40.30) the number of leaves (4.64), age flowering and harvesting the shortest contained in the genotype Hare Bauk Morin ie flowering date (39 days) and time of harvest (105 days), number of panicles highest in genotype Mean Hare, high-yielding varieties IR64, Ciherang and Cimelati. While the longest panicle length contained in the genotype Foam Hare, Hare Hare Fafulu and Fulan. the number of filled grains per panicle most contained in superior varieties IR64, Ciherang and Cimelati. A weight of 1000 grains is highest $p$ there are varieties Cimelati (vu3) with Hare Bauk Morin, IR64, and varieties Cherang highest rice yield for local rice genotypes present in Hare Bauk Morin (G3) of 9.79 ton. $\mathrm{Ha}^{-1}$ while yielding varieties contained in Ciherang (vu2 ) of 9.74 ton. $\mathrm{Ha}^{-1}$.

\section{Acknowledgment}

The authors would like to thank the Ministry of Education of East Timor that has financed the author to continue his studies at the University of Brawijaya Indonesia.

\section{References}

[1] Alavan A, R. Hayati, dan E. Hayati. 2015. Pengaruh pemupukan terhadap pertumbuhan beberapa varietas padi gogo (Oryza sativa L.) J. Floratek (10) $61-68$.

[2] BPS. (2014). Rata-rata Konsumsi Kalori per Kapita Sehari Menurut Kelompok Makanan 1999, 2002-2013. http://www.bps.go.id/.(diakses 5 Pebruari 2018).

[3] BPS. 2015. Konsumsi Rata-Rata per Kapita Seminggu Beberapa Macam Bahan Makanan Penting, 2007-2014. https://www.bps.go.id/linkTabelStatis/view/id/950. (24 Februari 2017)

[4] Burmana D., B. Majia, S.Singhb, S. Mandala, S. K. Sarangia, B.K. Bandyopadhyaya, A.R. Bala, D.K. Sharmac, S.L. Krishnamurthyc, H.N. Singhd, A.S. delosReyese, D. Villanuevae, T. Parise, U.S. Singhb, S.M. Haefelef, M. Abdelbagi. 2017. Participatory evaluation guides the development and selection of farmers'preferred rice varieties for salt- and flood-affected coastal deltas of South and Southeast Asia. Article In Press. 1-12.

http://dx.doi.org/10.1016/j.fcr.2017.03.009

[5] Dobermann, A. dan T. Fairhurst. 2000. Rice: Nutrient Disorders and Nutrient Management. Potash \& Potash Institute/Potash \& Potash Intitute of Canada.

http://www.ipni.net/ppiweb/filelib.nsf/0/2BB52995AF6F76E248257074002997BC/\$file/TOC\%2 0Rice\%20HB.pdf (akses 28 Pebruari 2017)

[6] Dwidjoseputro, D., 1992, Pengantar Fisiologi Tumbuhan. Gramedia Pustaka Utama. Jakarta. 
[7] Edi Mukhlis.2000. Penampilan dan komponen keragaman sifat kuantitatif galur-galur padi sawah dataran rendah pada berbagai jarak tanam. Tesis S2. Program Pasca Sarjana Universitas Andalas. Padang.

[8] FAOSTAT (FAO Statistical Service) 2011. At <http://faostat.fao.org>, Food and Agriculture Organization of the United Nations: Rome. (27 Pebruari 2017).

[9] Guan, Y., Hu, J., Wang, X., Shao, C., 2009. Seed priming with chitosan improves maize germination and seedling growth in relation to physiological changes under low temperature stress. J. Zhejiang Uni. Sci. B. 10, 427-433.

[10] Ismail, A.M., Ella, E.S., Vergara, G.V., Mackill, D.J., 2009. Mechanisms associated with tolerance to flooding during germination and early seedling growth in rice (Oryza sativa L.). Ann. Bot. 103, 197-209.

[11] Kato, Y., M. Okami, K. Katsura, 2009. Yield potential and water use efficiency of aerobic rice (Oryza sativa L.) in Japan. Field Crops Res. 11, 328-334.

[12] Lehar L., 2012. Pertumbuhan kentang (Solanum tuberosum L.) di dataran medium akibat perlakuan pupuk organik dan tricoderma sp. Jurnal Biotropical Sains, Jurnal Biologi FST UNDANA. 9(2):57-67.

[13] Lehar L., T. Wardiyati, M. D. Maghfoer, A. Suryanto. 2017. Influence of mulch and plant spacing on yield of Solanum tuberosum L. cv. Nadiya at medium altitude. International Food Research Journal 24(3): 1338 - 1344. http://www.ifrj.upm.edu.my/24\%20(03)\%202017/(60).pdf.

[14] Lingga, P. 1998. Petunjuk Penggunaan Pupuk. Penebar Swadaya, Jakarta.

[15] Lubis, E. Suwarno dan M. Bustaman. 1999. Genetik Ketahanan Beberapa Varietas Lokal Padi Gogo terhadap Penyakit Blas. Balai Penelitian Tanaman Padi Sukamandi. Penelitian Pertanian Tanaman pangan V. 18:2:1999. Puslitbangtan.

[16] Nugroho K, Slamet, P.Lestari. 2017. Keragaman Genetik 24 Varietas Padi Sawah Dan Padi Gogo (Oryza Sativa L.) Indonesia Berdasarkan Marka SSR. Scripta Biologica 4(1): 5-10.

[17] Osman, F. 1996. Memupuk Tanaman Padi dan Palawija. Penebar Swadaya, Jakarta.

[18] Sadimantara G.R., A. Widarsih, Muhidin. 2013. Seleksi beberapa Progeni Hasil Persilangan Padi Gogo (Oryza sativa L.) Berdasarkan Karakter Pertumbuhan Tanaman. Jurnal Agroteknos 3(1): 48-52.

[19] Sarangi, S.K., Maji, B., Singh, S., Sharma, D.K., Burman, D., Mandal, S., Ismail, A.M.,Haefele, S.M., 2014. Crop establishment and nutrient management for dry season (boro) rice in coastal areas. Agron. J. 106, 2013-2023. http://dx.doi.org/10.2134/agronj14.0182.

[20] Sarangi, S.K., Maji, B., Singh, S., Sharma, D.K., Burman, D., Mandal, S., Singh, U.S.,Ismail, A.M., Haefele, S.M., 2016. Using improved variety and management enhances rice productivity in stagnant flood-affected coastal zones. Field Crops Res. 190, 70-81. http://dx.doi.org/10.1016/j.fcr.2015.10.024.

[21] Sipaseuth, B.J., Fukai, S., Farrell, T.C., Senthonghae, M., Sengkeo, P.S., Linquist, B.,Chanphengsay, M., 2007. Opportunities to increasing dry season rice productivity in low temperature affected areas. Field Crops Res. 102, 87-97.

[22] Sitompul, S. M. dan Guritno. B. 1995. Pertumbuhan Tanaman. UGM Press. Yogyakarta.

[23] Wang W, S. Peng, H. Liu, Ye Tao, J.Huanga, K.Cui, L.Nie. 2017. The possibility of replacing puddled transplanted flooded rice with dry seeded rice in central China: A review. Field Crops Research. (214) 310-320. http://dx.doi.org/10.1016/j.fcr.2017.09.028

[24] You, A., X. Lu, H. Jin, X. Ren, K. Liu, H. Yang, G. Yang, L.Zhu, and G. He. 2006. Identification of quantitative traitloci accross recombinant inbred lines and testcrosspopulations for traits of agronomic importance in rice.Genetics 172:1287-1300.

*Corresponding author.

E-mail address: laurensiusl@ yahoo.co.id 